\title{
Impact of Leadership Style on Organization Commitment: In A Mediating Role of Employee Values
}

\author{
M. Suleman Sabir, *Adil Sohail, Muhammad Asif Khan \\ Iqra University Islamabad, Pakistan \\ *adil.sohail@hotmail.com
}

\begin{abstract}
This paper aims to how leadership ship style effects the organization commitment of the employees, when the organization culture is reflecting the employee's values in the organization. This paper is a conceptual based paper which gives theoretical evidence to support the idea. The paper also gives a brief overview of transactional leadership and transformational leadership. The results of the paper suggest that the leadership style is a strong dimension of organization commitment when organization culture of the organization represents the employees' values in the organization. Employees are more satisfied if the organization will meet their expectations which are the part of that organization culture, so they are more committed with the organization. The paper is not giving any empirical evidence of the model. Further studies can be carried out by replacing transactional leadership with servant leadership.
\end{abstract}

Keywords: Organizational culture; Transactional leadership; Transformational leadership; organization commitment; employee values

\section{Introduction}

The workforce of the organizations is more aware, educated, knowledgeable and expecting better values for themselves on the other hand organizations also want to better utilize them to get maximum benefits. Employees' Commitment with the organization reduces their intentions to leave the organization and remains the part of organization to work with more effectively and loyalty (Pascal et al, 2011). If the workforce is not committed in the organization then Job insecurity, low trust, high stress and uncertainty will increase in the organization, which have ultimately negative effect on the performance of the organizations (Panayiotis et al, 2011). Organization commitment can also increase the creativity in the organizations (Carlos and Filip, 2011). Societal culture has also impact on the leadership style of the management so that the leadership style in the organization may vary from society to society (Mujtaba et al, 2011). For the better performance of the organization, organizational commitment is one of strong determinant of success which is highlighted various times in the past literature (Chew and Chan, 2008, Das, 2002). Leadership and its effectiveness is primary focus for profit organization to achieve the organizational goals and to create organization commitment in their employees, for their organizations. Many researchers and scholars presented different theories regarding the leadership effectiveness and its relationship to organizational performance in early days (Blake and McCanse, 1991). Researchers mainly focused on the narrow aspects of leadership style including transactional leadership and transformational leadership (Burn, 1978; Bass, 1985).

Various past studies cover different aspects of leadership and its relationship with organizational commitment. Swanepoel, Eramus, Van Wyk and Scheck (2000) describe the organizational commitment is encouraged with the leadership style for the successful implementation of business strategies to achieve the organizational goal. Research conducted on the leadership style and its relationship with organizational commitment (Lo, Ramayah \& Min, 2009) and concluded that transactional and transformational leadership positively correlated with organizational commitment. Lo, Ramayah, Min \& Songan (2010) conducted the research on the leadership style and organizational commitment as a mediating role of leader member exchange and provide direction for further study; conflict can be reduce between the leader and subordinate when culture reflect the employee values. The study will investigate the relationship of employee value with organizational culture and how to provoke a sense of commitment in employee to increase the level of attachment with the organization which reduces the employee turnover and absenteeism. While discussing its importance for Pakistan, the study also gives a direction to the policy makers to increase the commitment of their employees by changing the leadership style in the organizations. Commitment smooth's the process of achieving organizational goals and 
objectives. Pakistan is a developing country and its organizations are facing a common problem of high turnover in their organization. The reason is that the employees switches to other organizations because of slightly better pay or additional benefits as compare to existing organizations.

\section{Literature Review}

Organizational Commitment: The definition of Commitment and its measurement changed with the passage of time. Few definitions are presented; when the person extraneous interest exist at consistency line, it become commitment (Becker, 1960), degree of attachment with the organization is called commitment (Reilly and Chatman, 1986). Organizational commitment is divided into two major parts in light of views; one is attitude and other is behavior. Employee feeling and thinking about the organization refer to attitude commitment while pattern of individuals are fixed into the organizations refer to behavioral commitment.

Various author purposed different models for commitment such as three components model of Meyer and Allen, Reilly and Chatman Model and other multidimensional model. Commitment associated with various dimensions which affect the organization in different ways. Major three dimensions of commitments are complains, Identification and moral (Reilly and Chatman, 1986). The model of organization commitment developed by the Mayer \& Allen (1991) included three level of commitment; affective, continuous and normative. They introduce dimension of commitment on the base of observation and identified three form of commitment; affective commitment, continuous commitment and normative commitment. The employee relationship with the organization varies employee to employee and reflects different degree of attachment with the organization. It is possible one employee has more affective commitment while other do not have, also possible that few employees have affective and normative commitment toward the organization and do not have continuous commitment. Therefore the degree of employee attachment with the organization changes person to person.

Affective commitment shows the level of employee attachment with the organization including beliefs, willingness and desire regarding organizational goal achievements. Affective commitment of employees toward the organization has three different shapes; one is identification, second is formation and third is maintaining. In affective commitment, emotions for the organization form at the beginning stage and then made identification of emotions with the organizational goals and objectives, finally try best to maintain these emotions toward the organization. Therefore Jaros et al. (1993) says that affective commitment of employee is a psychological attachment with the organization. Affective commitment has close relationship with the personal characteristics, age, gender, tenure, and organizational characteristics. Normative commitment is referred to the loyalty to the employee with the organization and employee has obliged feeling toward the organization. Obligations are development in the employee, when employee knows about the investment of organization on him/ her. In the starting stage of feeling of obligation, employee has known about organization time and money investment on his/ her training. This establish a feeling of remain with organization which is also called moral commitment.

Employees have different stakes/benefits attached with their organization which are given to them at the time of retirement. It is called continuous commitment or emotional attachment of the employees. Continuous commitment is based on the Becker's Bet theory (1960) which state that employee made long investment of time in the organization and leaving the organization give loss, therefore employee show intention to stay with the organization. The investment of employee in the organization includes time, work, effort, abilities and relationship with other employees which cannot found in next job. Therefore the turnover of the employees remains low in the organization and overall there is a positive effect on the performance of the organizations. This is also psychological attachment of employee with organization because employee perception of loss. Major variables associated with the continuous commitment are investment and alternative employment.

Transactional Leadership: Transactional Leadership is a type of leadership style which is commonly used in behavior sciences. The pioneer of transactional leadership is Burns (1978) that describe the transactional leadership as exchange the relationship between leader and subordinates. Major focus of transactional leaders is follower role clarification and leaders have to know about the needs of employee which require meeting the organizational goals. 
Bass and Stogdills (1990); and Avolio et al. (2004) discuss the attributes of the transactional leadership in two ways, first is contingent rewards and other is management by exception. Hellriegel and Slocum, (2006) explain that transactional leadership based on three primary components; contingent reward, active management by exception and passive management by exception. In contingent reward, transactional leader provide reward in exchange of achieving targets and these targets are set on the basis of short term and measurable. In active management by exception, leader monitors the subordinate performance and eliminates the deviation of subordinate from the path of goal. In passive management by exception, transactional leader interface in the matter of employee when subordinate give unaccepted performance. Transactional leadership is one who switches over interaction among subordinates for rewards and increasing their productivity. In nutshell that transactional leadership provides benefit at the achievement of goals while penalties at not a chieving the targets.

Transformational Leadership: Transformational leadership traced in evaluation context during 1978 by developing theory of transformational leadership and enriched with different aspect with the passage of time. Burns (1978) published a book on leadership which differentiates the transformational leadership from the traditional leadership. The Burn's theory of transformational leadership explained that leader has more moral quality and leader scarifies own interest over the group interest. Burn's theory of leadership is enhanced by Bass (1985) presenting transformational leadership in context of formal theory, model and factors measurements.

Tichy and Devanna (1986) presented characteristics regarding the estimation of transformational leadership including qualities, courage, openness, values, learning and ability of visionary. These transformational abilities have specific attributes while Avolio and Bass $(1988,1994)$ classified the leadership skills into 4 I's including idealized influence, inspirational motivation, intellectual stimulation and individualized consideration. Transformational leadership theory is the leader's power of motivating the subordinates for achieving more than already planned by followers (Krishnan, 2004). Bass and Riggio (2006); Baldoni (2005) and many other researchers agree that transformational leadership has four elements including idealized influence, inspirational motivation, intellectual stimulation and individualized consideration. Managerial ability is another ability of transformational leadership which is also essential for leader. The transformational leadership cannot implement effectively without some major attributes of leadership including creativity, team orientation, and appreciations, teaching power, responsibility and recognition (Parry, 1996). The qualities of transformational leadership with elements are basic for management success (Simic, 1998). Leader behavior toward the employees or subordinates should be reflecting respect, trust and faith. Leader actions build the respect for other, display a sense of responsibility, scarify own benefits over the employee benefits and remove all obstacles in the way of subordinate progress.

Organizational Culture: Hofstede refer culture as software of the mind that support in our daily interaction. The pattern of feeling and thinking of each person is different from others and identify the different aspects of culture. Lewis cultural model has three subset which are multi-active, linear active and reactive. The multi-active set included family, relationship, loyalty and emotion while linear active contain facts, planning, product and law. The reactive subset included courtesy, face, collective harmony and common obligation. Edgar Schein's model of culture included the three layer artifacts, espouse values and assumptions. The researcher identify three level of culture which are; artifacts, justification level and assumptions. Iceberg cultural model is used to taken better understanding of behavior.

The idea about the nature of culture has variation in presentation according to anthropology. Roy D' Andrade describe the cultural model as represent something and non declarative knowledge which gain from society. General principle of self organization is to use maximum power at low cost with optimum result. The power is maximized by energy of high quality, increase inflow, adapted and stable system and work to next large system. To increase the turnover, high ability to exploration, varied input and larger feedback organization take such action which increase the commitment of the employees with the organization, thus this effects the performance of the organization positively. According to Deal and Kennedy's cultural model, failure or success of the organization is based on corporate culture. Always weak culture leads to failure while strong culture leads to success. Success of the organization is also depends on the type of culture prevailing in the organization. In 1982 Terrence Deal and Kennedy presented their first model of organization culture in a book and which is based on the following six elements. 
- History-Traditions of past

- Values and Beliefs-What organization stand for and really important

- Rituals Ceremonies-Employees activities that bring together

- Stories- For employee better understanding

- Heroic Figure-Role model for others

- Cultural Network-Network of culture within organization

In initial definition of organization culture revolves around the concept of organization level and strong/weak culture. The strong culture has positive effect on the behavior of employee and it increase the employee commitment and performance which is good for organization while weak culture has negative impact on the organization performance and employees. Therefore in weak culture, need to improve their behavior and expression in direction of organization culture.

Employee Values: Employee value means the expectations of an employee from its employer against its contribution and performance. Effective employee values help the organizations to maximize the performance of the employees, retains the loyal workforce, reduce new hire premium and attract the talent for the organization (Talentsoothie, 2010). Attributes and benefits which have positive effect on the motivation of the candidates so that they will prefer to work for the organization and existing workers will stay in the organization. According to the CLC (Corporate leadership council) following are the attributes of Employee value proposition.

- Compensation

- Stability

- Development opportunities

- Future career opportunities

- Respect

- Manager quality

- Collegial work environment

Figure 1: Propose Model

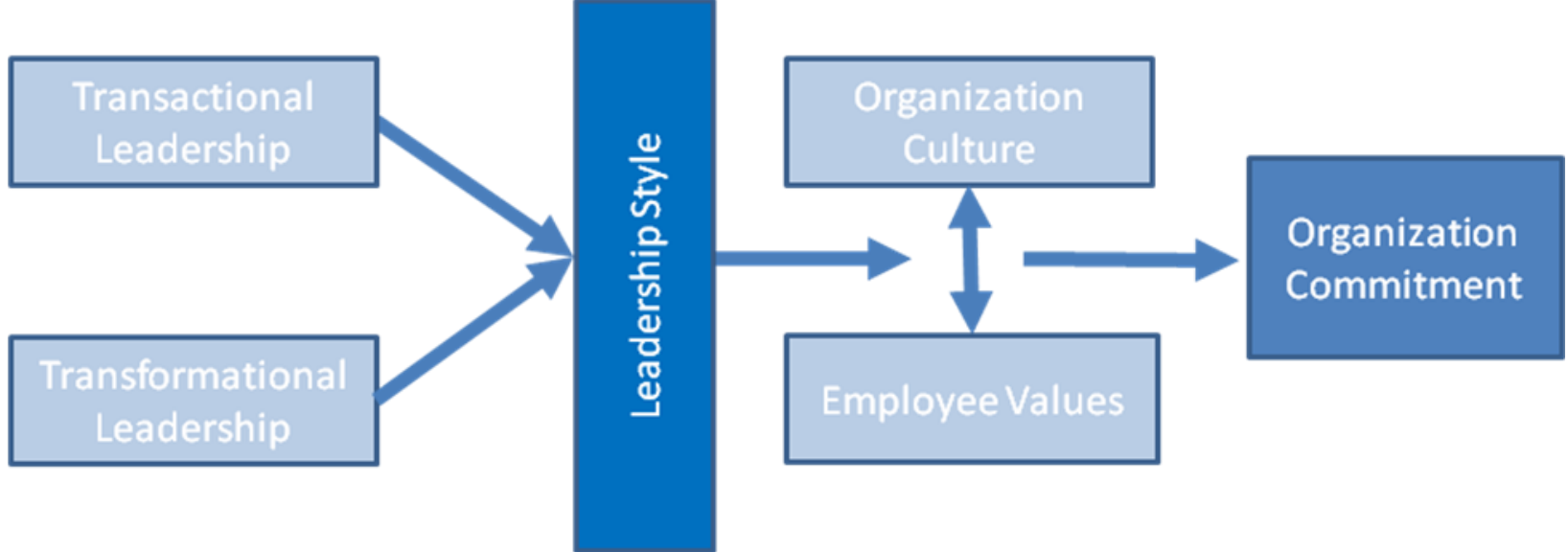

In proposed model you can see that organization commitment is taken as dependent variable and Leadership style is taken as independent variable. Employees' values representing organization culture are taken as moderating variable. Leadership style was constituted by transactional leadership and transformational leadership. In this model basically employee values are the part of the organization culture however organization culture also includes other dimensions also (continuous learning, quality etc) but here we will only take the employees' values in the organization.

\section{Mehtodology}

This paper aims to provide a conceptual understanding through literature reviews. The concept is that how leadership style effects the commitment of the employees in the organization. After defining all the main variables of this study theoretical evidences proves that employees' values are the part of organization culture and organization culture is effected by the leaderhip style of the organization. Paper provides link between leadership style and organization commitment and shows that how organization 
commitment can be increased by leadership style, when organization culture reflects the values of the employees.

\section{Discussion}

Efficiency of the organization relies on the leadership style in the organization through communicating policies and plans, rules and regulations, offering incentives, instructions, co-operation and build efficient work environment which facilitates the employees in a positive way. The pioneer of transactional leadership is Burns (1978) which describes the transactional leadership as exchange the relationship between leaders and subordinates. Transactional leadership provides benefit at the achievement of goals while penalties at not achieving the targets. Hellriegel and Slocum, (2006) explains that transactional leadership has three subscale; contingent reward, management by exception (active) and management by exception (passive). The Burn's theory of transformational leadership explained that leader has more moral quality and leader scarifies own interest over the group interest. Transformational leadership theory is the leader's power of motivating the subordinates for achieving more than already planned by followers (Krishnan, 2004). Avolio and Bass in 1988 and 1994 classified the leadership skills into 4 I's including Idealized influence, Inspirational motivation, Intellectual stimulation and Individualized consideration.

Leadership and Organizational Commitment: Researchers paid more attention on the transactional and transformational leadership. The behavior of both leadership style consider strong determinant of organization success (Laohavichien et al., 2009). Transformational leadership encourages the subordinates and gives way of critically thinking which affect the employee commitment (Avolio \& Bass, 1994). Transformational leadership is considered as one of the most influencing factor which has a positive effect on employee commitment in Indian bank's employees (Rai and Sinha, 2000). Various studies conducted on leadership style (Bateman and Strasser, 1984; Decotiis and Summers, 1987; Mathieu and Zajac, 1990) claimed that there is a strong positive relationship between leadership and organizational commitment. In 1999 Price, enhanced this research and suggested that subordinates confidence and trust on leader leads to the increase the commitment of the employees with the organizations. Aronold, Basling and Kelloway (2001) claimed that transformational leadership style helps the leader in enhancing their employees' trust and commitment. Transformational leader gives the solution of the problems frequently, which enhances motivation and commitment of employee (Lawler, 2003).

If the management of the organization tries to satisfy the needs of its employees the commitment of the employee will also increase and employee will prefer to remain the part of the organization (Hamdia and Phadett, 2011). If Leadership style has greater importance for the organization in context of increasing commitment (Blau, 1985) and leadership style is considered as antecedent of commitment (Willims and Hazer, 1986). Riaz and Haider (2010) concluded that transformational and transactional leadership positively correlated with the job success and satisfaction while transformational leadership found more significant and strong relationship with job success and career satisfaction as compared to transactional leadership. To bring the organization commitment Transformational leaders has strong influence on employees as compare to transactional leaders. Sub elements of transformational leadership such as intellectual stimulation, inspiration, idealized influence are significantly correlated with the organizational affective and normative commitment. Inspirational motivation and idealized consideration are not correlated significantly with continuous commitment while inspirational motivation and individual consideration has significant and positive relationship with organizational continuous commitment (Lo, Ramayah, Min \& Songan, 2010). Most recent researches on the leadership style and organizational commitment (Marmaya, Torsiman and Balakrishnan, 2011) shows that transformational and transactional leadership have positive relationship with employees' organizational commitment while employees of Malaysian organization are more influenced by transformational than transactional.

Leadership Style and Organizational Culture: Organizational culture is a major determinant of employee motivation and commitment which improves the organization performance. Past literature on the leadership relationship with the culture reveal various forms of behavior and attitude which based on culture environment. This variation comes from the different workforce ideas (Bass, Jung and Avolio; 1999 \& Yamaguchi, 1999) and also leadership style varies culture to culture (Dorfman et al, 2004; wood 
and Jogulu, 2006). Several researchers proved the linkage between leadership and organizational culture (Bass, 1985; Doherry, 1991; Trice and Beyer, 1991). Bass (1985) conducted study on leadership style and its impact on culture and found that transactional leaders operate in a boundary of existing culture, while transformation leaders operate to align the culture of the organization with vision of the organization. Schein (1992) inter correlate leadership and organizational culture. Organizational culture reflects the values and beliefs of founder and shaped the traits of organization. Hartog, Muijen and Koopman (1997) provide a link between transactional and transformational leadership with the culture and found positive relationship between leadership style and organization culture. Organizational culture and leadership depend on each other and leader establishes the values, norms and behaviors of employees within culture (Bass and Riggio, 2006). Jogulu (2010) found that leadership style changes as the culture of the organization changes. Schimmoeller (2010) concluded that transactional and transformational leadership have positive relationship with clan and adhocracy culture. Jaskyte (2004) made exploratory study on transformational leadership and organizational culture for not-for-profit organizations. Transformational leadership has positive relationship on cultural vale and leadership support the organization in developing strong culture in organization.

\section{Conclusion}

Organizations have to build up strong culture in the organization for success. Various organizations in Pakistan are facing the problem of absenteeism, high employee turnover and reputation of the organization for qualified workforce which can be overcame through strong culture which reflects the employee values. Strong culture always represents and can be established by the leadership that increases the organizational commitment. Leader can control the employee with the planning and monitoring tools (dashboard) that also measure organizational culture. Leader can eliminate that uncertainty and improve their commitment through establishing organizational culture and employee values must be the main part of this culture.

Leader can established organizational culture which reflects the employee value proposition in the organization and this bring lot of benefits toward the organization. When organizational culture and employee value proposition are same, it increased the commitment of employee's especially in new hired employee and this idea is also supported by the research of corporate leadership council. The mediating role of employee's values and strong organizational culture in the relationship of leadership style and organizational commitment help the organization in increasing commitment, attract more talented people, and retain the existing employees in the organization.

Limitation and Future Research: The research paper is based on the conceptualization while not on the qualitative and quantitative study. Better results can only be achieved through leadership style if proper compensation system prevails in the organization. However, there are other factors also which constitutes culture in the organization such as personal initiatives, innovation, quality, communication etc. While getting the better result other factors of the organization culture must also be controlled. These are the limitations of this study

It is also recommended that future research can be conducted by talking other factors of the organization culture. Future research can be conducted after introducing new technology in the organization or in industry; change in higher level management also gives directions for future research. Same study can be enhanced by applying qualitative or quantitative research approach in the study. Introducing new variable i.e. servant leadership style in the model by replacing the transactional leadership can also provide base for future research.

\section{References}

Riaz, A. \& Haider, M. H. (2010). Role of Transformational and Transactional Leadership on Job Satisfaction and Career Satisfaction. BEH-Business and Economic horizons , 1(1), 29-38.

Arnold, K. A., Barling, J., \& Kelloway, E. K. (2001). Transformational leadership or the iron cage: Which predicts trust, commitment and team efficacy? Leadership and Organization Development Journal, 22(7), 315-320. 
Avolio, B. J., \& Bass, B. M. (1988). Transformational leadership, charisma, and beyond. In J. G. Hunt, B. R. Baliga, H. P. Dachler, \& C. A. Schriesheim (Eds.), Emerging leadership vitas (29-49). Lexington, MA: Lexington Books.

Avolio, B. J. \& Bass, B. M. (1994). Improving organizational effectiveness through transformational leadership. California: Sage.

Avolio, B. J., Bass, B. M., \& Jung, D. I. (1999). Re-examining the components of transformational and transactional leadership using the Multifactor Leadership Questionnaire. Journal of Occupational \& Organizational Psychology, 9(72), 441-462.

Avolio, B. J., Zhu, W., Koh, W. L., \& Bhatia, P. (2004). Transformational leadership and organizational commitment: Mediating role of psychological empowerment and moderating role of structural distance. Journal of Organizational Behavior, 25, 951-968.

Mujtaba, G. B., Afza, T. \& Habib, N. (2011). Leadership Tendencies of Pakistanis: Exploring Similarities and Differences based on Age and Gender. Journal of Economics and Behavioral Studies, 2(5), 199-212.

Baldoni, J. (2005). Great Motivation Secret of Great Leaders. McGraw Hill Professional.

Bass, B. M. (1985). Leadership and performance beyond expectations. Free Press: New York.

Bass, B. (1990). Bass \& Stogdill's handbook of leadership (3rd Ed.). New York: The Free Press.

Bass, B. M., \& Riggio, R. E. (2006). Transformational Leadership (2 ed.). Mahwah, NJ: Lawrence Erlbaum Associates Inc.

Bateman, T. S. \& Strasser, S. (1984). A longitudinal analysis of the antecedents of organizational commitment. Academy of Management Journal , 27 (1), 95-112.

Becker, H. S. (1960). Notes on the concept of commitment. Am. J. Sociol. 66, 32-40.

Blake R. \& McCanse, A. (1991). Leadership dilemmas-Grid solutions. Grid management and organizational development, Gulf Co.

Blau, G. (1985). The measurement and prediction of career commitment. Journal of Occupational Psychology, 58, 277-88.

Burns, J. M. (1978). Leadership. New York: Harper \& Row.

Carlos, M. P. \& Filipe, C. (2011). From personal values to creativity: evidence from frontline service employees. European Journal of Marketing, 45 (7/8), 1029-1050.

Das, H. (2002). The four faces of pay: an investigation into how Canadian managers view pay. International Journal of Commerce \& Management, 12, 18-41.

DeCotiis, T. and Summers, T. (1987). A path analysis of a model of the antecedents and consequences of organizational commitment. Human Relations, 40(7), 445-70.

Hartog, D. Muijen, J. \& Koopman, P. (1997). Transactional versus transformational leadership: An analysis of the MLQ. Journal of Occupational and Organizational Psychological, 70, 19-34.

Dorfman, W., \& Hanges, J. (1997). Culture and leadership: A connection information processing model. Advance in Global Leadership, 4(7), 7-37.

Hamdia M. \& Phadett T. (2011). Conceptual framework on the relationship between human resource management practices, job satisfaction, and turnover, Journal of Economics and Behavioral Studies, 2(2), 41-49.

Harrison M. \& Trice, J. M. (1991). Cultural leadership in organizations. Organization Science , 2 (2), 149164.

Hellriegel, D. \& Slocum, J. (2006). Organizational behavior (11 th Ed.). Mason, OH: South Western

Chew, J. \& Chan C. C. (2008). HR practices, Organizational Commitment and intention to stay. International Journal of Manpower, 29(6), 503-522.

Jaros, S. J., Jermier, J. M., Koehler, J. W. \& Sincich, T. (1993). Effects of continuance, affective and moral commitment on the withdrawal process: An evaluation of eight structural equation models. Academy of Management Journal, 36(5), 951-995.

Jaskyte, K. (2004). Transformational leadership, organizational culture and innovativeness in non profit organizations. Non profit Management and Leadership, 25 (2), 153-168.

Jogulu, U. D. (2010). Culturally linked leadership style. Leadership and Organizational Development Journal, 31(8), 705-719.

Jogulu, U. \& Wood, G. (2006). The role of leadership theory in raising the profile of women in management. Equal Opportunities International , 25, 236-250.

Krishnan, V. R. (2004). Impact of transformational leadership on followers' influence strategies. Leadership and organization Development Journal, 25(1), 58-72.

Laohavichien, T., Fredendall, L., and Cantrell, R., (2009). The effects of transformational and transactional leadership on quality improvement. The Quality Management Journal, 16(2), 7-24. 
Lawler, E. E. (2003). Reward practices and performance management system effectiveness. Organizational Dynamics, 32(4), 396-404.

Marmaya, N. H., Hitman, M., Torsiman, N. N. \& Balakrishnan, B. (2011). Employee's perception of Malaysian managers' leadership styles and organizational commitment. African Journal of Business Management, 5(5), 1584-1588

Mathieu, J. E. \& Zajac, D. M. (1990). A review and meta analysis of the antecedents, correlates and consequences or organizational commitment. Psychological Bulletin, 108(2), 171-194

Lo, M. C., Ramayah, T., \& Min, H. (2009). Leadership styles and organizational commitment: A test on Malaysia manufacturing industry. African Journal of Marketing Management, 1(6), 133-139.

Lo, M. C., Ramayah, T., Min, H. \& Songan, P. (2010). Relationship between Leadership Styles and Organizational Commitment in Malaysia: Role of Leader-Member Exchange. Asia Pacific Business Review, 16(1-2), 79-104.

Meyer, J. P. \& Allen, N.J. (1991). A Tree-component conceptualitazation of organizational commitment. Human Resource Management Review, 1, 61-89.

Panayiotis, S., Pepper, A. \& Phillips, M. J. (2011) Transformational change in a time of crisis. Strategic HR Review, 10(5), 28-34.

Parry, K. W. (1998). Grounded theory and social process: A new direction for leadership research. Leadership Quarterly, 9, 85-105.

Pascal, P., Pierre-Sébastien, F. \& Lamontagne, S. (2011). Relationships between commitments to the organization, the superior and the colleagues, and the intention to leave among trucker. International Journal of Organizational Analysis, 19(2), 92-108.

Rai, S. S. (2000). Transformational leadership, organizational commitment relations between transformational leadership and work outcomes. Journal of Occupational Review , 21, 1-36.

Schein, E. H. (1992). Organizational culture and leadership (ed. 2nd), Jossey-Bass Management Series.

Schimmoeller, L. J. (2010). Leadership styles in competing organizational culture. Leadership Review , 10, 125-141.

Simic, I. (1998). Transformational leadership: The key to successful management. Organizational Change , $1(6), 49-55$.

Swanepoel B, Erasmus B, VAN Wyk, M. \& Sckeck, H. (2000). South African Human Resource Management: Theory and Practice. Kenwyn: Juta.

Talentsoothie (2010). Employee Value proposition infosheet: talentsoothie.com

Tichy, N. M., \& Devanna, M. A. (1986). The transformational leader. New York: Wiley.

Williams, L. J. \& Hazer, J. T. (1986). Antecedents and consequences of satisfaction and commitment in turnover models: a re-analysis using latent variable structural equation methods. Journal of Applied Psychology, 72(1), 219-31.

Yamaguchi, I. (1999). Effect of national culture and organizational types of workers on the job related orientations of Japanese, US and Australian employee. Leadership and Organization Development Journal , 20, 36-45. 